\title{
Development of Histology Teaching Materials of Five Human Organs Magazine Based on Corel Draw for Student at IKIP Budi Utomo Malang
}

\author{
Septina Dwi Prasetyana ${ }^{1)}$, Eka Corneliawati $^{1)}$ \\ ${ }^{1}$ Biology Education, IKIP Budi Utomo Jl. Citanduy 46 Malang \\ email: septinadwiprasetyana@gmail.com
}

\begin{abstract}
The purpose of this study was to develop a new learning media in the form of a magazine to support the histology learning process. The presence of the Five Human Organs Magazine is expected to provide a new learning atmosphere during the learning process, and to be able to provide new information on the topic of histology of the five organs of the human body, namely the brain, lungs, stomach, heart and liver. The development model used in this study was $4 D$ development model from Thiagarajan (1974). The 4D model has 4 stages, namely define, design, develop, and disseminate. But in this study it was only carried out until the develop stage without disseminate stages. The sample used in the trial was a class A of 2016 consist of 40 students. Data obtained by means of questionnaires. The results showed that the development of teaching materials for five human organs magazines was suitable to use in learning activities. This was indicated by the result expert validation which revealed that the product was very good. Validation result for learning media and learning design were said to be very good. Individual and group trial data said that the product was very good. In the medium group trial it can be concluded that the teaching material of the five human organs magazine is suitable to be used as a reference for the histology teaching material by students in IKIP Budi Utomo Malang.
\end{abstract}

Keywords: Histology teaching materials, magazine, five human organs.

\section{INTRODUCTION}

Histology is one of the courses taken by students of the biology education program at IKIP Budi Utomo Malang. Histology courses focus on the network of tissues that exist in humans. Students consider that this subject is difficult to study since it requires deep thinking and good memory. This research aimed to help students understand the involvement of the medical world in biology education. Students will be interested in studying human histology, they will understand and understand if there is a unique phenomenon in medical disciplines, so that in the minds of students there will be a dynamic of thinking and having answers during the learning process.

The results of the 2016 observation in the histology course found that students have several disadvantages include learning achievement that were below the standard value of 75. The weakness in application of human histology especially in giving information, and observing tissues. The magazine on five human organs will provide a new learning atmosphere for students. Several criteria adopted in this magazine such as attractiveness, design innovation, color images that match the original, and information that is easy to understand.

Based on the description and problems identification related to the need for teaching materials in the Human Histology course, Corel Draw-based teaching materials were developed to improve student learning outcomes with the help of Five Human Organs Magazine. The product will add student's collection of good and valid learning materials. Students will become more confident in expressing opinions, asking questions and suggestions and learning objectives can be achieved properly.

\section{RESEARCH METHOD}

The development of this teaching material used 4D model proposed by Thiagarajan et al. (1974). This model consists of 4 stages which are Define, Design, Develop, and Disseminate. This research used only 3 stages or until develop stage.

Bioedukasi Vol. XVI. No. 2 Oktober 2018

Received 9 August 2018 | Received in revised form 8 September 2018 | Accepted 22 September 2018 | Published

online 1 October 2018 
The trial stage consist of individual and small group. Individual trial with 5 respondents while small group trial with 12 respondents. All respondents were undergraduate students in the major of Biologi which had already taken the Human Histology course from IKIP Budi Utomo Malang.

There were two types of data produced, qualitative and quantitative data. Qualitative data was in the form of comments, criticisms, suggestions and inputs written by validators and students as users. Quantitative data were obtained based on scaled sheet scores by validators and questionnaires response. All data then used to improve teaching materials.

\section{RESULT AND DISCUSSION}

The presentation of the data describes the presentation of the results of responses / assessments from the material experts, as well as experts in media and design learning, individual trials, and group trials. In the validation stage, each assessment was given an assessment questionnaire and a printout product of the five human organs magazine histological teaching material for the score.

The content expert validation

Table 1. Result of content expert validation.

\begin{tabular}{|l|c|c|}
\hline \multicolumn{1}{|c|}{ Aspects } & Score & Description \\
\hline $\begin{array}{l}\text { The ability of title to describe } \\
\text { content coverage. }\end{array}$ & 4 & Very good \\
\hline $\begin{array}{l}\text { Using communicative } \\
\text { language and easy to } \\
\text { understand. }\end{array}$ & 4 & Very good \\
\hline $\begin{array}{l}\text { The content reflects the } \\
\text { description of 5 organs in the } \\
\text { human histology (brain, lung, } \\
\text { stomach, heart, liver). }\end{array}$ & 4 & Very good \\
\hline $\begin{array}{l}\text { Contain scientific truth, } \\
\text { according to the latest accurate } \\
\text { valid and scientific } \\
\text { developments. }\end{array}$ & 4 & Very good \\
\hline Contextual value & 4 & Very good \\
\hline $\begin{array}{l}\text { The accuracy of the concepts } \\
\text { and definitions. }\end{array}$ & 3 & Good \\
\hline $\begin{array}{l}\text { The facts, data and opinions } \\
\text { presented is accurate in } \\
\text { accordance with research and } \\
\text { is efficient to improve the } \\
\text { understanding of the reader. }\end{array}$ & 4 & Very good \\
\hline $\begin{array}{l}\text { The images, pictures, photos } \\
\text { are presented accurately. }\end{array}$ & 3 & Good \\
\hline $\begin{array}{l}\text { Accuracy of technical terms in } \\
\text { accordance with the norms } \\
\text { that apply in the field of } \\
\text { human histology. }\end{array}$ & 4 & Very good \\
\hline
\end{tabular}

\begin{tabular}{|l|c|c|}
\hline \multicolumn{1}{|c|}{ Aspects } & Score & Description \\
\hline $\begin{array}{l}\text { Presentation of content } \\
\text { provides information and } \\
\text { fosters curiosity or motivation. }\end{array}$ & 4 & Very good \\
\hline $\begin{array}{l}\text { The content is presented } \\
\text { systemically in stages, and use } \\
\text { simple, straightforward } \\
\text { language. }\end{array}$ & 4 & Very good \\
\hline $\begin{array}{l}\text { Presentation of content is in } \\
\text { accordance with the } \\
\text { characteristics of histology } \\
\text { course. }\end{array}$ & 4 & Very good \\
\hline Total scores & $\mathbf{4 6}$ & \\
\hline
\end{tabular}

Suggestion from the content expert covered the quality and the explication of the pictures presented.

\section{The Learning Media and Instructional Design} Expert Validation

Table 2. Result of Learning Media Expert Validation.

\begin{tabular}{|l|c|c|}
\hline \multicolumn{1}{|c|}{ Aspects } & Score & Description \\
\hline Size and Format & 4 & Very good \\
\hline Paper quality & 4 & Very good \\
\hline Printout quality & 4 & Very good \\
\hline Cover design & 4 & Very good \\
\hline Consistency in the layout & 4 & Very good \\
\hline Harmony of the layout & 4 & Very good \\
\hline Quality of typography & 3 & Good \\
\hline Consistency in numbering & 4 & Very good \\
\hline $\begin{array}{l}\text { Accuracy of illustrations, } \\
\text { graphics, images and photos }\end{array}$ & 4 & Very good \\
\hline $\begin{array}{l}\text { Matching and balanced color } \\
\text { combination }\end{array}$ & 4 & Very good \\
\hline Language clarity & 3 & Good \\
\hline Simplicity and attractiveness & 4 & Very good \\
\hline Total scores & $\mathbf{4 6}$ & \\
\hline
\end{tabular}

Suggestion from the learning expert comprised of improving the font size of pictures caption and the color quality of several pictures.

Individual Trial Test

Individual trials were conducted by five students of the Biology Education Study Program IKIP Budi Utomo Malang. Individual trial data included typographical errors, punctuation errors, words that should use uppercase or lowercase letters, etc.

Table 3 Result of Individual Trials

\begin{tabular}{|c|c|l|}
\hline Page & Row & Typo words and other errors \\
\hline 19 & 24 & Lobules = Lobulus \\
\hline 19 & 16 & Menyintesis = Mensistesis \\
\hline 27 & 9 & Gajah = Gadjah (UGM) \\
\hline 28 & 22 & Meiningkatkan = Meningkatkan \\
\hline 6 & 11 & Comma after the word Stellate \\
\hline
\end{tabular}

\section{Bioedukasi Vol. XVI. No. 2 Oktober 2018}




\begin{tabular}{|c|c|l|}
\hline 25 & 26 & $\begin{array}{l}\text { Excessive spaces after quotation } \\
\text { mark }\end{array}$ \\
\hline 6 & 1 & fitoestrogen = Fitoestrogen \\
\hline 32 & 3 & Namun = namun \\
\hline 20 & 5 & Jika = jika \\
\hline 15 & 1 & $\begin{array}{l}\text { (lambung), not separated by } \\
\text { space }\end{array}$ \\
\hline 19 & 8 & $\begin{array}{l}\text { Epitel permukaan, separated by } \\
\text { space }\end{array}$ \\
\hline
\end{tabular}

\section{Small Group Trials}

This trial was conducted on twelve students who had taken histology courses.

Table 4. Result Of Small Group Respons

\begin{tabular}{|l|c|}
\hline \multicolumn{1}{|c|}{ Aspects } & $\begin{array}{c}\text { Average } \\
\text { Score }\end{array}$ \\
\hline $\begin{array}{l}\text { Cover design makes you interested in } \\
\text { studying the materials. }\end{array}$ & 42 \\
\hline $\begin{array}{l}\text { The title has attracted your attention to } \\
\text { learn more. }\end{array}$ & 45 \\
\hline $\begin{array}{l}\text { The language used in the presentation } \\
\text { of material is simple, straightforward, } \\
\text { communicative and easily understood. }\end{array}$ & 43 \\
\hline $\begin{array}{l}\text { The display of images / photos can } \\
\text { make it easier for you to learn. }\end{array}$ & 44 \\
\hline $\begin{array}{l}\text { The system of content presentation } \\
\text { makes it easy for you to understand } \\
\text { the whole material in stages. }\end{array}$ & 41 \\
\hline $\begin{array}{l}\text { Provide knowledge, learning } \\
\text { motivation, and student creativity. }\end{array}$ & 42 \\
\hline $\begin{array}{l}\text { Encourage the growth of independent } \\
\text { learning skills. }\end{array}$ & 40 \\
\hline Total Score & $\mathbf{2 9 7}$ \\
\hline Percentage & $\mathbf{8 8 , 3 9}$ \\
\hline
\end{tabular}

Comments and suggestions from students are presented in Table 5 .

Table 5. Students Comments And Suggestions.

\begin{tabular}{|c|l|}
\hline Respondent & \multicolumn{1}{|c|}{ Comments } \\
\hline $\mathrm{R} 1, \mathrm{R} 2, \mathrm{R} 9$ & $\begin{array}{l}\text { a. Interesting learning material. } \\
\text { b.Cover is good, but some pictures are } \\
\text { not in good quality. }\end{array}$ \\
\hline $\mathrm{R} 3, \mathrm{R} 4$ & $\begin{array}{l}\text { All in all, the learning material is good } \\
\text { although some pictures need to be } \\
\text { replaced. The language used is simple, } \\
\text { easy to understand. Jack up curiosity } \\
\text { and motivation to read. }\end{array}$ \\
\hline $\mathrm{R} 5, \mathrm{R} 7, \mathrm{R} 8$ & $\begin{array}{l}\text { Need improvement on content, } \\
\text { writing and language. }\end{array}$ \\
\hline $\mathrm{R} 6, \mathrm{R} 10$ & $\begin{array}{l}\text { The product is good and innovative to } \\
\text { implement in histology course. }\end{array}$ \\
\hline $\mathrm{R} 11, \mathrm{R} 12$ & $\begin{array}{l}\text { Improvement on glosary. There are } \\
\text { several technical words that do not } \\
\text { exist in glosary. }\end{array}$ \\
\hline
\end{tabular}

The Ministry of National Education (2006) states that teaching materials or instructional materials generally consist of knowledge, skills, and attitudes that students must learn in order to achieve predetermined competency standards. In detail, the types of learning material consist of knowledge (facts, concepts, principles, procedures), skills, and attitudes or values.

Histology is the study of tissue structure in detail using a microscope on a thin tissue preparation. Histology can also be called microscopic anatomy. According to Banks in Khaisar (2006), histology is a branch of anatomical biology that studies the structure of cells that have the same physiological functions arranged into one complex network. When there is a change in cell structure due to disease, pathogens, the presence of hazardous substances such as heavy metals, or because of changes in physical factors (temperature) and chemistry (salinity, $\mathrm{pH}$ or DO) environment, it indicates that there has been a change or even ongoing change on environmental conditions. Histology analysis can be a very sensitive parameter and becomes very important in determining cell structure changes that occur in internal organs such as kidneys, liver and gonads (Dutta in Khaisar, 2005).

Magazine is type of mass media that consists of a set of printed paper put together. The writings in the magazine are made not by handwriting, but by a printing press. There are no standard provisions in compiling the contents of a magazine. Magazines usually contain various kinds of writing topics that are in accordance with the objectives and topics of the magazine in question. Not only writings, there are also pictures in the magazine that aim as illustrations to make the contents of the magazine more attractive. These images can be in the form of pictures of people, pictures of objects, or cartoons.

According to Frazier (1986), magazines can be divided into two parts which are general magazines and special magazines. General magazines are magazines that use problems that have significance for many people. Regarding politics, economics, education, culture and science which cover human needs in society. Special magazines are magazines that raise problems or findings such as agriculture, economics, engineering, science of science and others (Suhandang, 1988). 


\section{CONCLUSION}

Based on the results, it can be concluded that the product of development, Corel Drawbased Five Human Organs Magazine, was validated and ready to use in teaching learning activity.

Further development might be required especially to cover other topics both in human histology or other subject of contents. In addition, it is also necessary to complement printed magazine with online link to provide it with appropriate videos or footages

\section{REFERENSI}

Khaisar 2006. Kandungan Timah Hitam $(\mathrm{Pb})$ dan Kadmium (Cd) dalam Air, Sedimen dan Bioakumulasi Serta Respon Histopatologis Organ Ikan Alu-alu (Sphyraena barracuda)di Perairan Teluk Jakarta http://media.unpad.ac.id.

Depdiknas. 2006. Pedoman Memilih dan Menyusun Bahan Ajar. http://ktsp.diknas.go.id.

Dutta, et, al. 1996. Pengetahuan Embriologi. Penebar Swadaya. Jakarta

Frazier Bond, 1986. Psikologi Klinis. Jurnal hasil riset. e-jurnal.com/2013

Khaisar et al. (2005). Marine Ecology. New York: Oxford University Press.

Khaisar, L. G., Schuff, N., Cashdollar, N. \& Weiner, M. W., 2008, Age-Related Glutamate and Glutamine Concentration Changes in Normal Human Brain: 1H MR Spectroscopy Study at 4 T, NCBI, 26, 665-672.

Suhandang, 1988. Psikologi Klinis. Jurnal hasil riset. e-jurnal.com/2013.

Thiagarajan, Sivasailam, dkk. (1974). Instructional Development for Training Teachers of Exceptional Children. Washinton DC: National Center for Improvement Educational System.

Bioedukasi Vol. XVI. No. 2 Oktober 2018 